\title{
PEDAGOGICAL CONDITIONS FOR BUILDING COMPETENCE IN TEACHING PAINTING TO FUTURE ARTISTS
}

\author{
ПЕДАГОГІЧНІ УМОВИ ФОРМУВАННЯ КОМПЕТЕНТНОСТІ \\ В ПРОЦЕСІ НАВЧАННЯ ЖИВОПИСУ У МАЙБУТНІХ ХУДОЖНИКІВ
}

\begin{abstract}
The article deals with identifying and substantiating the pedagogical conditions for building future artist's competence in teaching painting. For this purpose, the author reviewed scientific literature on the definition of the concepts of "pedagogical conditions"; "competence"; "integrative course". Research methods. The study used a complex of interrelated and complementary methods, namely the study of scientific materials, design, and generalization of teaching experience. The aim of the article is the theoretical substantiation of the pedagogical conditions for building competence in teaching painting to future artists. The results of the study proved that it is necessary to introduce a complex of the following pedagogical conditions for successful building of future artist's competence, namely: building the educational process in accordance with the developed model of the future artist's competence building; development of independent and creative activities of students during training in creative workshops, where various types of arts are used; the creation of specially arranged conditions conducive to the development of the personality of students based on the integration of the possibilities of various types of art and the corresponding types of activity in the socio-cultural and subject space of a higher educational institution. The processes of modernization of education have led to a change in the requirements for university graduates, for their professional training, which should result in the developed competence in the field of professional activity. With regard to the preparation of future artists in teaching painting, this result is competence, which is the ability and readiness for the effective art education and aesthetic education of the younger generation, ensured by the value attitude towards the profession, psychological, pedagogical and special knowledge, professional skills, and experience of artistic assimilation of reality.

Key words: pedagogical conditions, competence, painting, integrative course, principles.
\end{abstract}

UDC 371.13:7.071.1

DOI https://doi.org/10.32843/2663-

6085/2021/32-1.5

Dr. Ayad hayawi Al Atabi,

Doctor of Philosophy

Dhi-Kar University Media College «компетентність», «інтеграційний курс». Результати проведеного дослідження довели, що для успішного фрормування компетентності у майбутнього художника необхідно впровадити комплекс таких педагогічних умов, як побудова освітнього процесу відповідно до розробленої моделі формування компетентності у майбутніх художників; розвиток самостійної і творчої діяльності студентів під час навчання в творчих майстернях, де використовують різні види мистецтв; створення спеціально організованих умов, що сприяють розвитку особистості учнів на основі інтеграції можливостей різних видів мистецтва і відповідних їм видів діяльності в соціокультурному і предметному просторі вищого навчального закладу. Безумовно, малювання з натури є основою навчального процесу під час підготовки художників. Під час створення виробу необхідно вміння представляти будь-яку форму в різноманітних положеннях $і$ зображати ії в потрібному ракурсі, що вимагає чіткого уявлення предмета, його деталей $і$ конструкції, знань натури. В процес натурного малювання на основі ретельного відбору і вивчення окремих фрактів, аналізу конструкції, пластики форми, просторового положення, текстури виділяються найбільш важливі елементи, що складають основу зображуваного об'єкта або явища. Процеси модернізації освіти зумовили зміну вимог до випускників вищих навчальних закладів, до їх профресійної підготовки, результатом якої повинна стати сформована компетентність у галузі профресійної діяльності. Стосовно підготовки майбутніх художників в процесі навчання живопису таким результатом $є$ компетентність, яка являє собою здатність і готовність до ефрективного здійснення художньої освіти та естетичного виховання підростаючого покоління, що забезпечені наявністю у нього ціннісного ставлення до своєї профессіі, психолого-педагогічних і спеціальних знань, професійних умінь, досвіду художнього освоєння дійсності.

Ключові слова: педагогічні умови, компетентність, живопис, інтегративний курс, принципи.
Problem statement. The improvement of education entailed changes in the requirements for university graduates, for their professional training and methods of acquiring knowledge, abilities and skills. Today, the main goal of professional education is considered to be the training of a competent specialist, who is able to act practically, apply individual techniques and experience of successful actions in various situations of professional activity; who could navigate in related areas of activity at the level of world standards. Currently, there are fewer and fewer graduates who are able to fully apply knowledge gained during their studies at a university in their professional activities. This is a factor that hinders and hinders the development of the productive forces of society. Despite the significant theoretical elaboration of the problem of professional 
training of future artists, its practical implementation turns out to be insufficiently effective. In this context, an important component of our research is to improve the quality of professional training of future specialists, including artists, since there is a high need for specialists who have professional performing skills. That urged the research on the problem of determining the pedagogical conditions for building competencies of future artists in teaching painting.

Review of research and publications. The pedagogical background of building competence as a system was covered in the studies of the following scholars: P. Anokhin, S. Arkhangelsky, Y. Vardanyan, V. Vvedensky, N. Kuzmina, V. Slastenin. Certain issues of the professional development of the future artist are covered in the studies of L. Antsukov, A. Belov, N. Valkova, N. Voronov, V. Gamayunov, E. Lazarev. A great contribution to the development of the theory and practice of teaching art disciplines was made by educational scholars S. Azhgikhin, N. Baklanova, G. Ershov, Zh. Kenesarina, N. Lukin. They presented research related to the teaching methods of fine art subjects, including painting. Besides, ideas and recommendations developed by practicing artists presented in monographs (A. Dürer, B. loganson, I. Repin, P. Chistyakov) are of great importance for the purpose of studying the theoretical and practical background of painting. Analyzing a large number of scientific studies of building competence among specialists in various fields of activity, it indicates the interest of scholars in this problem. But, despite this fact, the study of the problem of building competence in teaching painting to future artists requires further study and coverage in the theory and practice of professional education. The need to study the process of building competence in teaching painting to future artists is due to the following contradictions between the need of modern society to harmonize and aestheticize the subject-spatial environment, its compliance with the nature of economic, social and political changes, and the low level of preparedness of university students as future artists for its transformation, between the need to improve competence in the process of studying painting by future specialists and the lack of a structural and functional model of its building in the educational process of higher educational institution, between the need to improve the quality of professional knowledge, skills that students acquired, as well as the development of the creative qualities of their personality, and the lack of developed pedagogical conditions to build them.

The study used a complex of interrelated and complementary methods, namely the study of scientific materials, design, and generalization of teaching experience.

The aim of the article is the theoretical substantiation of the pedagogical conditions for building competence in teaching painting to future artists.
Results. Modern requirements for the professional training of artists in teaching painting will require the introduction of a competence-based approach into the process of their professional training, which provides for the training of a specialist who understands professional and life challenges, is able to solve them and transform the social environment and his own professional activity, applying previously acquired knowledge, creative skills and abilities [1, p. 223]. The competence-based approach in education has now become the subject of active reflection in the works of such scholars of pedagogical science and practice as I. Zimnyaya, B. Kenzhebekov, V. Shadrikov, Sh. Taubaeva, K. Aganin. In their research, B. Ananyeva, V. Bespalka, T. Shamova studied the definitions of competence and comprehensively investigated the main aspects of professional competence, which have some specifics for future artists. In this regard, an important component of our research is the study of the professional training of future artists who are able to approve themselves in different areas of professional activity. The demand for a creative, qualified, competitive person is growing. The above urged research on the problem of determining the pedagogical conditions for building competencies of future artists in teaching painting. The developed pedagogical conditions are aimed at adapting students to creative and transformative activities in the situation of solving theoretical and methodological problems of training future artists in the system of building their professional competence. In modern pedagogical research, which is related to the problems of improving pedagogical systems, increasing efficiency of the educational process, one of the main aspects is to identify, substantiate and test pedagogical conditions in order to ensure successful activity [9]. A pedagogical condition means a set of measures and circumstances of the educational process, a system of reasonably built factors that contribute to the formation of competence in future artists. Our research allowed formulating pedagogical conditions, the implementation of which will contribute to building competence in future artists in teaching painting. The first pedagogical condition is building of the educational process in accordance with the developed model of building competence in future artists. Since the structural model of the process of building competence in future artists has a block structure, this allows it to be improved depending on the factors of the educational environment.

As Figure 1 shows, the model of building professional competence in future artists that we developed is a unity of such blocks as goal, conceptual, procedural and resultant.

The first block defines a goal, which is characterized by building competence in teaching painting to future artists.

The conceptual block includes scientific approaches (integrative, competent, acme logical and 


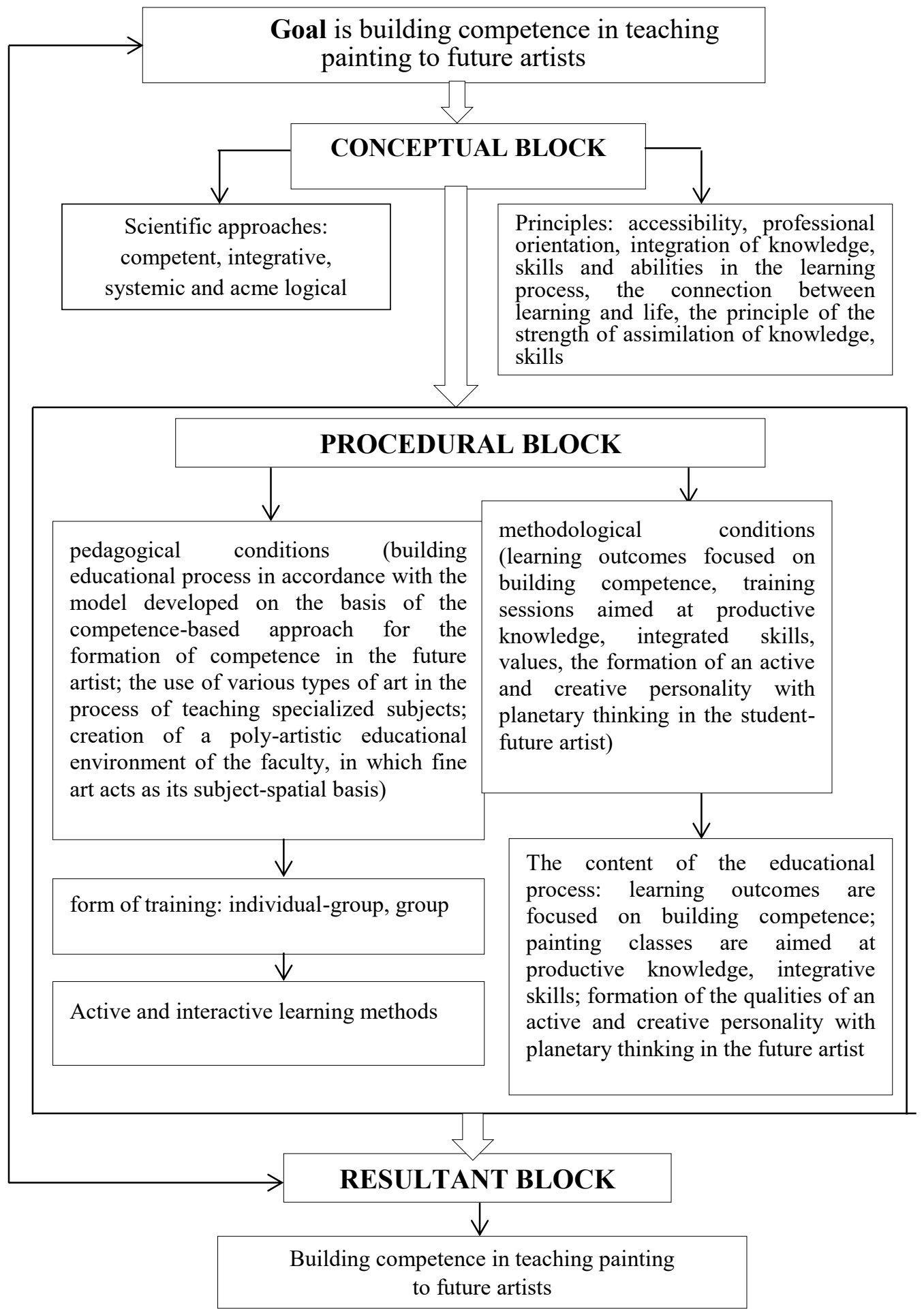

Fig. 1. Structural model of the process of building competence in future artists

systemic) and the principles of: accessibility, taking into account the level of knowledge for building relevant professional competencies; professional orientation reflected in the content of the training system and the nature of professional tasks; integration of professional, interdisciplinary, sociocultural, communicative knowledge, skills and abilities in the learning process; the connection of learning with life and the principle of strong assimilation of knowledge, skills and abilities.
The procedural block includes pedagogical conditions (building of the educational process in accordance with the developed model of building competence in the future artist; development of independent and creative activity of students during training in creative workshops, where various types of arts are used; creation of specially arranged conditions that contribute to the development of the personality of students based on the integration of the possibilities 
of various types of art and the corresponding types of activity in the sociocultural and subject space of a higher educational institution); methodological conditions (learning outcomes focused on building competence, training sessions aimed at productive knowledge, integrated skills, values, the formation of an active and creative personality with planetary thinking in the student-future artist); the content of the educational process (the use of pedagogical technologies, the implementation of the content of the author's course "Art" with the use of innovative pedagogical technologies, which are based on interactive teaching methods); forms of training (individual-group provides for the teacher's work with students of different ages, training levels in classroom-based and extracurricular learning, when he works separately with the student and can simultaneously teach the group through the formulation of cognitive tasks; frontal contributes to the trusting teacher-students relationships, stable cognitive interests; group provides for their division into groups for solving the same or different problems and forms collective responsibility as well as individual assistance to everyone) and methods (active and interactive learning).

The resultant block presents the expected results of building competence of future artists for professional activity in the context of our research, significant changes which may indicate the effectiveness of the proposed model during training.

The second pedagogical condition was proposed for the effective building of competence in future artists - this is the development of independent and creative activities of students during training in creative workshops, where various types of arts are used in teaching students the specialized subjects. The curriculum for training future artists in teaching painting assumes that in the learning process students become familiar with the basics of such types of arts as visual arts, architecture, sculpture, decorative and applied arts, which have a connection with their specialization and artistic training. In our opinion, this is not enough for training students. Therefore, we assume that the inclusion in the educational process of other types of art, namely: music, theatre, cinema, the creation of a poly-artistic educational environment of the faculty will help to improve the process of building competence in future artists. Besides, we proposed the following pedagogical conditions for building competence in future artists: the use of various types of art in teaching students the specialized subjects; creation of a poly-artistic educational environment of the faculty. Music, theatre and cinema were chosen as the main arts. It is also possible to listen to classical music as an accompaniment to the process of completing an assignment by students (performing a still life, landscape, portrait, etc.) in practical painting classes. It helps students concentrate on the assignment itself. At the same time, it is necessary to select musical works taking into account the assignments on which students are working at a given time [2, p. 44].

Theatre has a strong impact on people. Theatre educates and harmoniously develops a personality, teaches one to express oneself. Theatrical art can be used in the educational process outside academic hours. Cinema or motion picture art is a form of contemporary art, which are created using moving images. Films are divided into feature films and documentaries. The first shows the events played by the actors, the second - filmed in real life. Watching films about great artists (Surviving Picasso, Frida, Girl with a Pearl Earring, etc.) is essential when studying History of Fine Arts. Studies show that educational material presented in the form of a film is assimilated much better than the same material presented by a teacher [3]. A person accumulates experience of artistic assimilation of reality in the process of interaction with a work of art, which allows him to develop the value-motivational and cognitive spheres of his personality.

Of course, life drawing is the basis of the educational process in the preparation of artists. When creating a product, it is necessary to be able to represent any form in various positions and depict it in the desired perspective, which requires a clear presentation of the object, its details and design, knowledge of a model. In life drawing, the most important elements that form the basis of the depicted object or phenomenon are highlighted on the basis of careful selection and study of individual facts, analysis of the structure, and plasticity of form, spatial position, and texture. The accumulation of scientific knowledge and practical skills develops creativity and visual memory, the ability to observe and analyze the surrounding reality. Students must master the color literacy; know all the properties of colors and the ways of their interaction, the patterns of constructing harmonic relationships, take into account the relationship between form and color. The development of new constructive solutions for decorative and applied products based on natural material will attach the creative searches of future artist's solidity and scale. The formation of professional competence among future artists is directly related to the study of the history of traditional folk culture, which contributes to the assimilation of knowledge about other national cultures by students. Training of specialists with well-formed ideological, spiritual and moral qualities based on folk customs and traditions of both the global level and a specific region contributes to young people's entering a modern multi-ethnic, multicultural society, forms a system of values, behavioral norms, patriotism and national self-awareness [6].

The third pedagogical condition is the creation of specially organized conditions conducive to the development of the personality of students based on the integration of the possibilities of various types 
of art and the corresponding types of activity in the socio-cultural and subject space of a higher educational institution. The creation of an enriched developmental environment is a path that allows you to effectively develop students by means of pedagogical activity. The creative development of a person, like no other, requires the creation of a special educational environment, including external (social environment, education systems) and internal components (individual psychological qualities of a person). The greatest effect in human development is achieved with the joint and mutual influence of internal and external factors. The educational environment shall mean the socio-pedagogical and cultural environment of students, which is created purposefully and exists as a given, and creates conditions for their effective creative activity, revealing their inclinations and abilities. In our opinion, realization of the third pedagogical condition is possible through the use and development of appropriate integrative courses. Therefore, it is the integrative teaching of students and interdisciplinary connections of subjects within the curriculum that will improve the educational process make it goal-oriented and more effective. A close connection between subjects will ensure the development of creative thinking, the development of skills of generating original forms based on the traditions of the past. The purpose of interdisciplinary connections is based on the ability to master the techniques of transferring knowledge from one subject to another, which brings purposefulness and logical consistency to the learning process in solving creative problems. The interaction and semantic relationship between such subjects as Drawing, Painting, History of Traditional Culture, Design, and Formation does not exclude the specifics and independence of individual parts of the whole, while it involves the development of interrelated content based on common topics and tasks in the study of related subjects. While increasing the activity of students' independent work, an integrative approach to learning provides acquisition of systemic knowledge and skills as professional competence influencing the formation of a holistic worldview of students and allowing the future artist to solve complex multidimensional tasks in artistic and creative activities. The integration mechanism is implemented through the following stages of educational activity: intrasubject generalization and systematization, aimed at acquiring general knowledge and skills; intersubjective transfer of the acquired knowledge and skills; creative application by students of knowledge and skills acquired in their professional activity, leading to the acquisition of new knowledge and ways of action. Transfer should not be carried out mechanically, for example, when using any concept of one subject in the study of another, there can be an interpenetration of scientific and artistic knowledge in artistic and creative activity, as well as the selection of scientific and artistic methods that are significant for a given situation [4]. Theoretical integrative training involves student's mastery of a system of ground knowledge of special and social sciences, as well as methods and techniques of independent acquisition of new productive knowledge. Practical integrative training means student's mastery of a system of integrated skills and abilities, which allows them to apply the acquired knowledge in practice, while professional training of future specialists provides for the mastery of a system of productive knowledge, integrative and intellectual skills for future professional activities, contributing to the development of the creative abilities of the future specialist, perception of active life positions [9]. In addition, the formation of professional concepts at an integrative level contributes to the development of imaginative thinking in an individual, which can be described by the following properties: knowledge possessed by an individual is of an integration nature, since it is obtained in the process of studying various academic subjects; this knowledge is closely related to practice, since young people with professional thinking realize most ideas in the form of material objects; in their actions they operate with a system of abstract signs and symbols.

When forming the structure of the content of the integrative course, we adhered to the following algorithm: use of qualification characteristics, a model of a specialist's activity as sources of goal-setting for an integrative course; drawing up a preliminary list of integrative skills that a student should have on the basis of these sources; skills of formation and systematization of actions, determination of the main actions (the most important and responsible for professional activity, move to academic subjects which are based on the knowledge of the integrative course; formation of characteristics of actions with the definition of their properties; development of mechanisms for integrative quality control of the established goal of studying an integrative course based on: the ability to accurately check the achievement of the goal of an integrative course; compliance of the learning goal with the final goal of the integrative course; correction of the formulated goal of studying the integrative course [7]. All elements of the presented model of preparing the professional training of future artists in teaching painting are interrelated and interdependent, which confirms its integrity and consistency.

Conclusions. The processes of modernization of education have led to a change in the requirements for university graduates, for their professional training, which should result in the developed competence in the field of professional activity. With regard to the preparation of future artists in teaching painting, this result is competence, which is the ability and readiness for the effective art education and aesthetic education of the younger generation, ensured by the value attitude towards the profession, psychological, 
pedagogical and special knowledge, professional skills, and experience of artistic assimilation of reality. Building competence in future artists in teaching painting is effective when the following pedagogical conditions are realized: building of the educational process in accordance with the model of building future artist's competence, developed on the basis of the integrative approach; the use of various types of art in teaching students the specialized subjects; building the content of education based on the complementarity of subjects, the unity of goals, objectives and requirements, interdisciplinary relationships that play an important role in improving the theoretical and practical training of students.

\section{BIBLIOGRAPHY:}

1. Амиргазин К., Удалов С. Формирование компетентностей в процессе обучения декоративно-прикладному искусству. Омский научный вестник. 2012. № 2 (106). C. 223-225.

2. Бакум 3., Саприкіна Л. Педагогічні умови фрормування профресійної компетентності майбутніх дизайнерів одягу. Наукові записки Тернопільського педагогічного університету імені Володимира Гнатюка. Серія: Педагогіка. 2014. № 1. С. 44-49.

3. Бех І. Психологічні засади побудови виховного простору особистості Личность в едином образова- тельном пространстве : сборник научных статей Международного образовательного фрорума. Ч. 1. 2010. 240 c.

4. Гусева П. Формирование мастерства будущих художников палехской иконописи в высшей профессиональной школе : дисс. ... канд. пед. наук : спец. 13.00.08. Санкт-Петербург, 2012. 183 с.

5. Козак Л. Дослідження інноваційних моделей навчання у вищій школі. Освітологічний дискурс. 2014. № 1 (5). С. 95-106.

6. Мишина А. Развитие искусствоведческой компетенции бакалавров художественных фракультетОВ. НАУКОВЕДЕНИЕ. 2015. Т. 7. № 4. URL: https:// cyberleninka.ru/article/n/razvitie-iskusstvovedcheskoykompetentsii-bakalavrov-hudozhestvennyh-fakultetov (date of accessed: 27.06.2017).

7. Фомічова Н. Індивідуальність як інтеграційна характеристика творчого потенціалу живописця і завдання її фрормування в мистецькому ВН3. Мистецька освіта: зміст, технології, менеджмент. 2010. Вип. 5. URL: http://zbirnik.mixmd.edu.ua/ 2010_5_ua.

8. Хушбахтов А. Терминология «педагогические условия». Молодой ученый. 2015. № 23. С. 1020-1022.

9. Шокорова Л. Проблема профрессионального образования в сорере народных художественных промыслов и ремесел. Alma mater. 2014. № 3. C. $108-110$. 